\title{
ANALISIS FAKTOR-FAKTOR YANG MEMPENGARUHI KINERJA PEGAWAI PADA KANTOR DPRD PROVINSI SUMATERA SELATAN Vinkan Amanda Putri ${ }^{1,}$ Maliah $^{2}$
}

\author{
1'Mahasiswa jurusan Manajemen, Universitas PGRI, Sumatera Selatan \\ ${ }^{1)}$ Email: vinkanap1998@gmail.com \\ 2.'Dosen jurusan Manajemen, Universitas PGRI, Sumatera Selatan \\ ${ }^{2)}$ Email: maliahse1961@ gmail.com
}

\section{Submitted: \\ 08/12/2021 \\ Revised: \\ $20 / 12 / 2021$ \\ Accepted: \\ 25/12/2021 \\ Online-Published:}

INFORMASI ARTIKEL

$31 / 12 / 2021$

\begin{abstract}
ABSTRAK
Penelitian ini bertujuan untuk menganalisis faktor-faktor yang mempengaruhi kinerja pegawai pada kantor DPRD Provinsi Sumatera Selatan, faktor-faktor dalam penelitian ini dibatasi pada motivasi kerja dan disiplin kerja terhadap kinerja pegawai. Metode penelitian ini menggunakan metode kuantitatif yaitu metode dalam bentuk data dan angka dengan pendekatan deskriptif yaitu merumuskan dan menafsirkan data yang ada dan metode pengumpulan datanya dengan menyebarkan kuesioner (angket). Sampel dalam penelitian ini sebanyak 50 pegawai. Adapun analisis data dalam penelitian ini adalah dengan mengunakan program SPSS (Stasistical Product and Service Solution) versi 23. Teknik uji coba instrument dalam penelitian ini melipuli uji validitas dan uji reliabilitas dan kriteria pengujian hipotesis yaitu uji $t$ dan uji F.

Berdasarkan pengelolaan data diperoleh persamaan regresi linier berganda yaitu $Y=77,076+0,262 X_{1}+(-0,684) X_{2}+e$.

Berdasarkan uji hipotesis dengan uji $t$ maka hasil penelitian menunjukkan bahwa secara parsial motivasi kerja tidak berpengaruh signifikan terhadap kinerja pegawai, sedangkan disiplin kerja berpengaruh signifikan terhadap kinerja pegawai. Hasil uji $F$ diperoleh bahwa secara simultan motivasi kerja dan disiplin kerja berpengaruh secara bersama-sama terhadap kinerja pegawai.
\end{abstract}

Kata Kunci: Motivasi Kerja, Disiplin Kerja, Kinerja Pegawai

\begin{abstract}
This research aims to analyse the factors that affect the performance of employees in the DPRD office of South Sumatera Province, the factors in this research are limited to the motivation of work and work discipline towards employee performance. This method of study uses quantitative methods that are methods in the form of data and numbers with a descriptive approach that is to formulate and interpret the existing data and methods of collecting it by spreading the questionnaire (poll). The samples in this study were as much as 50 employees. The data analysis in this research is using SPSS program (Stasistical Product and Service Solution) version 23. The instrument testing techniques in the study covered the validity test and the reliability test and the hypothesis testing criteria is the T test and $F$ test.

Based on data management, it is obtained that the multiple linear regression equation is $Y=77.076+0.262 X 1+(-0.684) X 2+e$.

Based on the hypothesis test with the t test, the results showed that partially work motivation had no significant effect on employee performance, while work discipline had a significant effect on employee performance. The results of the f test show that simultaneously work motivation and work discipline have an effect on employee performance
\end{abstract}

Keywords: Motivation Work, Work Discipline, Employee Performance 


\section{A. PENDAHULUAN}

Salah satu hal terpenting untuk mencapai terlaksananya kegiatan organisasi atau perusahaan adalah dengan meningkatkan kinerja pegawai di setiap unit organisasi. Organisasi merupakan suatu sistem, yaitu rangkaian dan hubungan antara bagian komponen yang berkerja sama secara keseluruhan. Terdapat hubungan yang erat antara kinerja perseorangan dengan kinerja organisasi. Dengan kata lain bila kinerja pegawai baik kemungkinan besar kinerja organisai juga baik. Oleh karena itu organisasi harus benar-benar memperhatikan faktor sumber daya manusianya.

Organisasi merupakan sekumpulan orang-orang yang bekerja untuk mencapai tujuan tertentu, suatu organisasi sering kali berhadapan dengan berbagai macam masalah, kendala, dan keterbatasan yang menyebabkan gagal, kurang berhasil atau bahkan bubar. Organisasi saat ini menghadapi persaingan yang semakin ketat, setelah di berlakukannya Otonomi Daerah banyak bermunculannya peraturan-peraturan baru. Agar lembaga dapat bersaing, sangat perlu pengelolaan organisasi terutama pada faktor manusia, karena betapapun canggihnya suatu teknologi namun sumber daya manusia atau pegawai tetap merupakan faktor penggerak utama dalam kegiatan organisasi.

Kinerja merupakan bagian produktivitas kerja, dimana produktivitas berasal dari "produktif"artinya sesuatu yang mengandung potensi untuk digali, sehingga produktivitas dapatlah dikatakan sesuatu proses kegiatan yang terstruktur guna menggali potensi yang ada dalam sebuah komoditi atau objek. Filosofi produktivitas sebenarnya dapat mengandung arti keinginan dan usaha dari setiap manusia(individu maupun kelompok) agar selalu meningkatkan mutu kehidupan dan penghidupannya. Kinerja ialah gambaran gambaran mengenai tingkat pencapaian pelaksanaan suatu kegiatan/ program/kebijaksanaan dalam mewujudkan sasaran, tujuan, misi dan visi organisasiyang tertuang dalam skema strategis suatu organisi (Fahmi, 2011).

Kinerja yang baik merupakan modal yang penting yang harus dimiliki oleh aparatur negara, sebab menyangkut pemberian pelayanan publik. Namun ironisnya kinerja yang baik oleh pegawai secara umum masih tergolong rendah ini disebabkan banyaknya pelanggaran yang masih dilakukan oleh para pegawai. Pada organisasi, jika kinerja sumber daya manusia baik maka kinerja institusi pemerintah baik juga tetapi dalam kenyataannya , kinerja sumber daya manusia pemerintahan kita yang buruk juga mengakibatkan rendahnya kinerja pemerintahan.

Motivasi memiliki peran penting dalam peningkatan kinerja pegawai. Seorang pegawai akan dapat mencapai motivasi yang berlipat ketika ia merasakan ada peluang dalam mencapai tujuannya. Penghargaan dari pimpinan merupakan salah satu yang dapat memotivasi pegawai.

Dengan motivasi kerja yang tinggi, pegawai akan bekerja lebih giat dalam melaksanakan pekerjaannya. Begitupun sebaliknya dengan motivasi kerja yang rendah pegawai tidak mempunyai semangat kerja, mudah menyerah dan kesulitan dalam menyelesaikan pekerjaannya.

Masalah lainnya, terdapat sebagian pegawai yang sering menggunakan waktu kerja untuk hal-hal yang tidak produktif. Kondisi yang seperti ini, menunjukkan rendahnya tingkat disiplin kerja yang pada akhirnya akan mempengaruhi unit kerja dan lingkungan kerja secara keseluruhan. Kedisiplinan juga mempengaruhi kinerja pegawai. Dengan kedisiplinan pegawai yang baik dapat mencapai tujuan organisasi, sedangkan kedisiplinan yang merosot dapat menjadi penghalang dan menperlambat pencapaian tujuan organisasi.

Sementara disiplin kerja adalah suatu sikap, perilaku yang dilakukan secara sukarela dan penuh kesadaran serta keadaan untuk mengikuti peraturan yang telah ditetapkan instansi baik tertulis maupun tidak tertulis (Ayer, 2016:29). Tanpa disiplin pegawai yang baik, sulit bagi organisasi perusahaan atau instansi mencapai hasil yang optimal. Seorang Pegawai yang mempunyai tingkat kedisiplinan yang tinggi akan tetap bekerja dengan baik walaupun tanpa diawasi oleh atasan, tidak akan mencuri waktu kerja untuk melakukan hal-hal lain yang tidak ada kaitannya dengan pekerjaan, akan mentaati peraturan yang ada dalam lingkungan kerja dengan kesadaran yang tinggi tanpa ada rasa paksaan. Disiplin kerja pegawai bisa dilihat dari tingkat kehadiran dan ketepatan waktu datang ke 
kantor. Hal ini bisa dilihat dari tingkat absensi yang dicapai.

Permasalahan dalam penelitian ini dirumuskan sebagai berikut:

1. Apakah Motivasi berpengaruh terhadap kinerja pegawai pada kantor DPRD Provinsi Sumatera Selatan?

2. Apakah Disiplin berpengaruh terhadap kinerja pegawai pada kantor DPRD Provinsi Sumatera Selatan?

3. Apakah Motivasi dan Disiplin berpengaruh secara bersama terhadap kinerja Pegawai pada kantor DPRD Provinsi Sumatera Selatan?

Berdasarkan rumusan masalah yang telah dikemukakan, maka tujuan penelitian ini adalah.

a. Untuk mengetahui pengaruh motivasi terhadap kinerja pegawai pada kantor DPRD Provinsi Sumatera Selatan.

b. Untuk mengetahui pengaruh disiplin terhadap kinerja pegawai kantor DPRD Provinsi Sumatera Selatan.

c. Untuk mengetahui pengaruh motivasi dan disiplin terhadap kinerja pegawai kantor DPRD Provinsi Sumatera Selatan.

\section{Motivasi Kerja}

Motivasi adalah suatu faktor yang mendorong seseorang untuk melakukan aktivitas tertentu, oleh karena itu motivasi sering kali diartikan pula sebagai faktor pendorong perilaku seseorang. Oleh karena itu, faktor pendorong dari seseorang untuk melakukan suatu aktivitas tertentu pada umumnya adalah kebutuhan serta keinginan orang tersebut (Sutrisno, 2012:109).

Motivasi merupakan serangkaian proses yang membangkitkan (arouse), mengarahkan (direct), dan menjaga (maintain) perilaku manusia menuju pada pencapaian tujuan (Wibowo, 2016: 322).

$$
\text { Menurut Hasibuan (2013:143) }
$$

motivasi adalah pemberian daya penggerak yang menciptakan gairah kerja seseorang agar mereka mau bekerja sama, bekerja efektif, dan terintegrasi dengan segala daya upayanya untuk mencapai kepuasan.

Menurut Nawawi (2011:231) motivasi merupakan suatu kondisi yang mendorong atau menjadi sebab seseorang melakukan sesuatu perbuatan atau kegiatan, yang berlangsung secara sadar. Motivasi adalah suatu faktor yang mendorong seseorang untuk melakukan suatu aktivitas tertentu, oleh karena itu motivasi sering kali diartikan pula sebagai faktor pendorong perilaku seseorang (Sutrisno, 2012:146).

\section{Disiplin Kerja}

Kedisiplinan adalah kesadaran dan kesediaan seseorang menaati semua peraturan perusahaan dan norma-norma sosial yang berlaku (Hasibuan, 2011:193).

Sutrisno (2012:87) Disiplin adalah sikap hormat terhadap peraturan dan ketetapan perusahaan dan ketetapan perusahaan, yang ada dalam diri karyawan, yang menyebabkan ia dapat menyesuaikan diri dengan sukarela pada peraturan dan ketetapan perusahaan.

Rivai (2013:825) berpendapat bahwa disiplin kerja adalah suatu alat yang digunakan para manager untuk berkomunikasi dengan karyawan agar mereka bersedia untuk mengubah suatu perilaku serta sebagai suatu upaya untuk meningkatkan kesadaran dan kesediaan seseorang menaati semua peraturan perusahaan atau organisasi dan norma-norma sosial yang berlaku.

Terdapat empat perspektif dasar yang menyangkut disiplin kerja menurut rivai (2013:852):

1. Disiplin retributif (retributive disclipine) yaitu berusaha menghukum orang yang berbuat salah.

2. Disiplin korektif (corrective disiplibe) yaitu berusaha membantu karyawan mengkorekti perilaku yang tidak tepat.

3. Perspektif hak-hak individu (individual right perspective) yaitu berusaha melindungi hak-hak dasar individu selama tindakan disipliner.

4. Perspektif utilitarian (utilitarian perspective) yaitu berfokus pada penggunaan disiplin hanya pada saat konsekuensi-konsekuensi tindakan disiplin melebihi dampak negatifnya.

Disiplin kerja dapat diartikan kesadaran dan kesetiaan seseorang menaati peraturan perusahaan atau organisasi serta norma-norma sosial yang berlaku, dimana karyawan selalu datang dan pulang tepat waktu dan mengerjakan semua pekerjaannya dengan baik (Liyas dan Primadi 2017:24).

\section{Kinerja Pegawai}

Kinerja adalah hasil kerja yang dapat dicapai oleh seseorang atau sekelompok orang 
dalam suatu organisasi, sesuai dengan wewenang dan tanggung jawab masingmasing dalam rangka upaya mencapai tujuan organisasi bersangkutan secara legal, tidak melanggar hukum dan sesuai dengan moral dan etika (Sinambela, 2012:481).

Istilah kinerja berasal dari $J o b$ Performance atau Actual Performance (prestasi kerja atau prestasi sesungguhnya yang dicapai seseorang). Pengertian kinerja adalah hasil kerja secara kualitas dan kuantitas yang dicapai oleh seorang pegawai dalam melaksanakan tugasnya sesuai tanggung jawab yang diberikan kepadanya (Mangkunegara, 2011:67)

Hendri (2013:25) menyatakan bahwa kinerja merupakan hasil pekerjaan yang mempunyai hubungan kuat dengan tujuan strategis organisasi, kepuasan konsumen, dan memberikan kontribusi pada ekonomi. Dengan demikian kinerja adalah tentang melakukan pekerjaan dan hasil yang dicapai dari pekerjaan tersebut.

Menurut Moeheriono (2014:95) kinerja atau performance merupakan gambaran mengenai tingkat pencapaian pelaksanaan suatu program kegiatan atau kebijakan dalam mewujudkan sasaran, tujuan, visi dan misi organisasi yang dituang melalui perencanaan strategis suatu organisasi. Kinerja dapat diketahui jika individu atau sekelompok karyawan telah mempunyai kriteria atau standar keberhasilan tolak ukur yang ditetapkan oleh organisasi. Oleh karena itu, jika tanpa tujuan dan target yang ditetapkan maka kinerja seseorang atau organisasi tidak mungkin diketahui bila tidak ada tolak ukur.

Menurut Kaswan (2012:187), kinerja adalah suatu hasil atau tingkat keberhasilan seseorang secara keseluruhan selama periode tertentu di dalam melaksanakan tugas dibandingkan dengan berbagai kemungkinan, seperti standar hasil kerja, target atau sasaran, atau kriteria yang telah ditentukan terlebih dahulu dan telah disepakati.

Selanjutnya Handoko (2011:56) menyakatakan bahwa kinerja (performance appraisal) adalah proses melalui organisasiorganisasi mengevaluasi atau menilai prestasi kerja karyawan dimana dalam kegiatan ini dapat memperbaiki keputusan-keputusan personalia dan memberikan umpan balik kepada para karyawan tentang pelaksanaan kerja mereka.

\section{Hipotesis Penelitian}

Menurut Sugiyono (2017:134)

hipotesis merupakan jawaban sementara terhadap rumusan masalah penelitian, dimana rumusan masalah penelitian telah dinyatakan dalam bentuk kalimat pertanyaan.

H1 : Motivasi berpengaruh signifiksn terhadap kinerja pegawai pada kantor DPRD Provinsi Sumatera Selatan.

H2 : Disiplin berpengaruh signifikan terhadap kinerja pegawai pada kantor DPRD Provinsi Sumatera Selatan.

H3 : Motivasi dan Disiplin berpengaruh signifikan secara bersama-sama terhadap kinerja pegawai kantor DPRD Provinsi Sumatera Selatan.

\section{B. METODE PENELITIAN}

Objek penelitian ini dilakukan pada kantor DPRD Provinsi Sumatera Selatan yang beralamat: Jl. Kapten A. Rivai No.1, Lorok Pakjo, Kec. Ilir Bar. I, Kota Palembang, Sumatera Selatan. 30315.

Metode penelitian yang digunakan adalah metode kuantitatif dapat diartikan sebagai metode penelitian yang berlandaskan pada filsafat positivisme, digunakan untuk meneliti pada populasi atau sampel tertentu, pengumpulan data menggunakan instrumen penelitian, analisis data bersifat kuantitatif/ statistik, dengan tujuan untuk menguji hipotesis yang telah ditetapkan.

Populasi penelitian ini adalah seluruh pegawai kantor DPRD Provinsi Sumatera Selatan sebanyak 102 pegawai. Sampel yang diambil sebanyak 50 (dibulatkan) orang.

Teknik sampling yang digunakan pada penelitian ini adalah Probability Sampling, yaitu, teknik pengambilan sampel yang memberikan peluang yang sama bagi setiap unsur (anggota) populasi untuk dijadikan sampel (Sugiyono, 2017:82).

Sumber data yang dipergunakan dalam penelitian ini adalah, sebagai berikut:

a) Data Primer

Menurut Sujarweni (2019:89), Data Primer adalah data yang diperoleh dari responden melalui kuesioner, kelompok fokus, dan panel atau juga data hasil wawancara peneliti dengan narasumber. Data yang diperoleh dari data primer ini harus diolah lagi. Sumber data yang langsung memberikan data kepada pengumpul data. 
b) Data Sekunder

Menurut Sujarweni (2019:89), Data Sekunder adalah data yang didapat catatan, buku majalah berupa laporan keuangan publikasi perusahaan, laporan pemerintah, artikel, buku-buku sebagai teori, majalah dan lain sebagainya. Data yang diperoleh dari data skunder ini tidak perlu diolah lagi. Sumber yang tidak langsung memberikan data pada pengumpul data.

Teknik pengumpulan data dalam penelitian ini adalah:

a. Kuesioner (Angket)

Menurut Sugiyono (2017:230), kuesioner merupakan teknik pengumpulan data dimana responden mengisi pertanyaan atau pernyataan kemudian setelah diisi dengan lengkap mengembalikan kepada peneliti.

b. Observasi

Menurut Sugiyono (2017:234), adalah teknik pebgamatan secara langsung ditempat penelitian. Teknik pengumpulan data yang digunakan dalam penelitian ini merupakan suatu proses yang kompleks, suatu proses yang tersusun dari berbagai proses biologis dan psikiologis. Dua diantara yang penting adalah proses-proses pengamatan dan pengingat.

\section{Uji Coba Instrumen}

\section{a. Uji Validitas}

Menurut Priyatno (2018:21), uji validitas item digunakan untuk mengetahui seberapa cermat suatu item dalam mengukur apa yang ingin diukur. Item dikatakan valid jika adanya korelasi dengan skor totalnya. Kriteria pengujian dilakukan dengan menggunakan $r$ tabel pada tingkat signifikan 0,05 dengan uji 2 sisi, jika nilai positif dan $r$ hitung $>r$ tabel, item dapat dinyatakan valid. Jika $r$ hitung $<r$ tabe, item dinyatakan tidak valid.

\section{Uji Reliabilitas}

Menurut Priyatno (2018:25), uji reliabilitas dilakukan untuk mengetahui konsitensi alat ukur yang biasanya menggunakan kuisioner. Metode yang sering digunakan dalam penelitian untuk mengukur skala rentangan (seperti skala likert 1-5) adalah Cronbath Alpha. Uji reliabilitas adalah kelanjutan dari uji validitas, item yang masuk pengujian adalah item yang valid saja dan untuk menentukan apakah instrumen relibel atau menggunakan batasan 0,6 adalah kurang baik, sedangkan 0,7 dapat diterima dan diatas 0,8 adalah baik.

\section{Teknik Analisis Data Uji Normalitas}

Menurut Priyatno

normalitas data merupakan syarat pokok yang harus dipenuhi dalam analisis parametrik. Normalitas data merupakan hal yang penting karena dengan data yang terdistribusi normal, maka data tersebut dianggap dapat mewakili populasi. Dalam penelitian normalitas data diuji menggunakan uji one sample kolmogorov-smirnov test.

Dalam uji one sample kolmogorovsmirnov test, variabel-variabel yang mempunyai asympotic signifinance (2-tailed) diatas signifikan 0,05 maka diartikan bahwa variabel-variabel tersebut memiliki distribusi normal dan sebaliknya.

a. Jika sig $<0,05$ distribusi data tidak normal.

b. Jika sig $>0,05$ distribusi data normal.

\section{Uji Multikolinearitas}

Menurut Priyatno (2018:134), multikolineritas adalah keadaan pada model regresi ditemukan adanya korelasi yang sempurna atau mendekati sempurna antar variabel independen. Model regresi yang baik seharusnya tidak terjadi korelasi yang sempurna atau mendekati sempurna diantara variabel bebas (korelasinya 1 atau mendekati 1). Metode uji multikolinearitas yang umum digunakan dengan melihat nilai tolerance dan variance inflation factor (VIF).

Untuk mengetahui suatu model regresi bebas dari multikolinearitas yaitu mempunyai nilai variance inflation factor (VIF) kurang dari 10 dan mempunyai angka tolerance lebih dari 0,1 .

\section{Uji Heteroskedastisitas}

menurut Priyatno (2018:136), uji heteroskedastisitas adalah keadaan dimana dalam model regresi terjadi ketidaksamaan varian dari residual pada satu pengamatan ke pengamatan lain. Jika varian dari residual pada satu ke pengamatan lain tetap, maka disebut homoskedastisitas. Model regresi yang baik adalah yang berjenis homoskedastisitas atau tidak terjadi heteroskedastisitas. Uji statistik yang digunakan adalah Uji Scatter Plot. Dasar analisisnya adalah jika gambar menunjukkan 
titik-titik yang menandakan komponenkomponen dari variabel-variabel menyebar secara acak pada bidang scatter dapat disimpulkan tidak terjadi heteroskedastisitas.

\section{Analisis Regresi Linier Berganda}

Menurut Sujarweni (2019:160) regresi

linier berganda merupakan regresi yang memiliki variabel dependen dan memiliki satu variabel independen atau lebih. Pada penelitian ini menggunakan alat ukur SPSS versi 23, model persamaan regresi linier berganda sebagai berikut..

Rumus :

$$
\mathbf{Y}=\mathbf{a}+\mathrm{b}_{1} \mathbf{X}_{1}+\mathbf{b}_{2} \mathbf{X}_{2}+\mathbf{e}
$$

Keterangan:

Y : Kinerja pegawai

a : nilai konstanta

$\mathrm{X}_{1}$ : Motivasi Kerja

$\mathrm{X}_{2}$ : Disiplin kerja

$\mathrm{b}_{1}$ : koefisien regresi $\mathrm{X}_{1}$

$\mathrm{b}_{2}$ : koefisien regresi $\mathrm{X}_{2}$

$\mathrm{e}:$ Standar error of the estimate

\section{Koefisien Determinasi $\left(\mathbf{R}^{2}\right)$}

Menurut Siregar (2013:338) koefisien determinasi $\left(\mathrm{R}^{2}\right)$ adalah angka yang menyatakan atau digunakan untuk mengetahui kontribusi yang diberikan pada variabel bebas $(\mathrm{X})$ atau variabel terikat $(\mathrm{Y})$.

Rumus : $\quad \mathrm{R}^{2}=(\mathrm{r})^{2} \times 100 \%$

(Sumber siregar 2013:338)

$\mathrm{R}^{2}$ : koefisien determinasi

$\mathrm{r}^{2}$ : kuadrat koefisien determinasi

\section{Kriteria Penguji Hipotesis}

\section{a. Uji t (secara parsial)}

Menurut Priyatno (2018:121), uji t atau uji koeffisien regresi secara parsial digunakan untuk mngetahui variabel independen secara parsial berpengaruh secara signifikan atau tidak terhadap variabel dependen. Kriteria penerimaan dan penolakan hipotesis.

a. Jika sig<0,05, maka $\mathrm{H}_{\mathrm{o}}$ ditolskdan $\mathrm{H}_{\mathrm{a}}$ diterima.

b. Jika sig>0,05, maka $\mathrm{H}_{\mathrm{o}}$ diterima dan $\mathrm{H}_{\mathrm{a}}$ ditolak.

\section{b. Uji F (secara simultan)}

Menurut Priyatno (2018:119), uji f atau uji koefisien regresi simultan digunakan untuk mengetahui variabel independen berpengaruh signifikan terhadap dependen. Dalam hal ini untuk mengetahui apakah variabel motivasi kerja dan disiplin kerja berpengaruh signifikan atau tidak terhadap kinerja pegawai. Kriteria pengujian menggunakan tingkat signifikan 0,05 .

a. Jika sig $<0,05$, maka $\mathrm{H}_{\mathrm{o}}$ ditolak dan $\mathrm{H}_{\mathrm{a}}$ diterima.

b. Jika sig $>0,05$, maka $\mathrm{H}_{\mathrm{o}}$ diterima dan $\mathrm{H}_{\mathrm{a}}$ ditolak.

\section{HASIL PENELITIAN DAN PEMBAHASAN}

1) Hasil Penelitian

a. Uji Validitas

1. Variabel Motivasi Kerja $\left(X_{1}\right)$

Menurut Priyatno (2018:21), uji validitas item digunakan untuk mengetahui seberapa cermat suatu item dalam mengukur apa yang ingin diukur. Item dikatakan valid jika adanya korelasi dengan skor totalnya. Kriteria pengujian dilakukan menggunakan $\mathrm{r}_{\text {tabel }}$ pada tingkat signifikan 0,05 dengan uji 2 sisi, jika nilai positif dan $\mathrm{r}$ hitung $>\mathrm{r}$ tabel, item dapat dinyatakan valid. Jika $r$ hitung $<r$ tabel, item dinyatakan tidak valid . Hasil dapat dilihat dari tabel dibawah ini.

Tabel 1. Hasil Uji Validitas Variabel Motivasi $\operatorname{Kerja}\left(\mathbf{X}_{1}\right)$

\begin{tabular}{|c|c|c|c|c|}
\hline No & Keterangan & $\begin{array}{c}\text { Pearson } \\
\text { correlation } \\
\text { rhitung }\end{array}$ & $\begin{array}{c}r_{\text {tabel }} \\
a=0,05\end{array}$ & $\begin{array}{c}\text { Hasil } \\
\text { Validitas }\end{array}$ \\
\hline 1 & X.1 & 0,489 & 0,278 & Valid \\
\hline 2 & X.2 & 0,494 & 0,278 & Valid \\
\hline 3 & X.3 & 0,467 & 0,278 & Valid \\
\hline 4 & X.4 & 0,500 & 0,278 & Valid \\
\hline 5 & X.5 & 0,541 & 0,278 & Valid \\
\hline 6 & X.6 & 0,525 & 0,278 & Valid \\
\hline 7 & X.7 & 0,459 & 0,278 & Valid \\
\hline 8 & X.8 & 0,461 & 0,278 & Valid \\
\hline 9 & X.9 & 0,557 & 0,278 & Valid \\
\hline 10 & X.10 & 0,426 & 0,278 & Valid \\
\hline
\end{tabular}

Sumber : Hasil pengolahan data spss ver.23

Berdasarkan hasil uji validitas Motivasi kerja $\left(\mathrm{X}_{1}\right)$ tabel $1 \mathrm{di}$ atas bahwa hasil pengolahan data variabel motivasi kerja $\left(\mathrm{X}_{1}\right)$ menggunakan SPSS ver. 23, hasilnya bahwa semuanya lebih tinggi dari $r_{\text {tabel}}$, kesimpulannya bahwa seluruh pernyataan tersebut valid.

2. Variabel Disiplin Kerja $\left(\mathrm{X}_{2}\right)$

Berikut pengujian validitas pada variabel disiplin kerja (X2). Hasil dapat dilihat dari tabel dibawah ini. 
Tabel 2. Hasil Uji Validitas Variabel Disiplin $\operatorname{Kerja}\left(\mathbf{X}_{2}\right)$

\begin{tabular}{|c|c|c|c|c|}
\hline No & Keterangan & $\begin{array}{c}\text { Pearson } \\
\text { correlation } \\
\text { rhitung }\end{array}$ & $\begin{array}{c}\mathrm{r}_{\text {tabel }} \\
a=0,05\end{array}$ & $\begin{array}{c}\text { Hasil } \\
\text { Validitas }\end{array}$ \\
\hline 1 & $\mathrm{X} 2.1$ & 0,671 & 0,278 & Valid \\
\hline 2 & $\mathrm{X} 2.2$ & 0,763 & 0,278 & Valid \\
\hline 3 & $\mathrm{X} 2.3$ & 0,692 & 0,278 & Valid \\
\hline 4 & $\mathrm{X} 2.4$ & 0,666 & 0,278 & Valid \\
\hline 5 & $\mathrm{X} 2.5$ & 0,814 & 0,278 & Valid \\
\hline 6 & $\mathrm{X} 2.6$ & 0,730 & 0,278 & Valid \\
\hline 7 & $\mathrm{X} 2.7$ & 0,677 & 0,278 & Valid \\
\hline 8 & $\mathrm{X} 2.8$ & 0,705 & 0,278 & Valid \\
\hline 9 & $\mathrm{X} 2.9$ & 0,473 & 0,278 & Valid \\
\hline 10 & $\mathrm{X} 2.10$ & 0,597 & 0,278 & Valid \\
\hline
\end{tabular}

Sumber : Hasil pengolahan data spss ver.23

Berdasarkan hasil uji validitas Disiplin kerja $\left(\mathrm{X}_{2}\right)$ tabel 2 di atas bahwa hasil pengolahan data variabel disiplin kerja $\left(\mathrm{X}_{2}\right)$ menggunakan SPSS ver. 23, menunjukkan seluruh pearson correlation nilai lebih dari $\mathrm{r}_{\text {tabel }}$, merupakan seluruh pernyataan tersebut valid.

\section{Variabel Kinerja Pegawai (Y)}

Berikut pengujian validitas pada variabel kinerja pegawai (Y). Hasil dapat dilihat dari tabel dibawah ini.

Tabel 3. Hasil Uji Validitas Variabel Kinerja Pegawai (Y)

\begin{tabular}{|c|c|c|c|c|}
\hline No & Keterangan & $\begin{array}{c}\text { Pearson } \\
\text { correlation } \\
\mathrm{r}_{\text {hitung }}\end{array}$ & $\begin{array}{c}\mathrm{r}_{\text {tabel }} \\
a=0,05\end{array}$ & $\begin{array}{c}\text { Hasil } \\
\text { Validitas }\end{array}$ \\
\hline 1 & $\mathrm{X} 1.1$ & 0,438 & 0,278 & Valid \\
\hline 2 & $\mathrm{X} 1.2$ & 0,581 & 0,278 & Valid \\
\hline 3 & $\mathrm{X} 1.3$ & 0,546 & 0,278 & Valid \\
\hline 4 & $\mathrm{X} 1.4$ & 0,346 & 0,278 & Valid \\
\hline 5 & $\mathrm{X} 1.5$ & 0,517 & 0,278 & Valid \\
\hline 6 & $\mathrm{X} 1.6$ & 0,531 & 0,278 & Valid \\
\hline 7 & $\mathrm{X} 1.7$ & 0,314 & 0,278 & Valid \\
\hline 8 & $\mathrm{X} 1.8$ & 0,352 & 0,278 & Valid \\
\hline 9 & $\mathrm{X} 1.9$ & 0,495 & 0,278 & Valid \\
\hline 10 & $\mathrm{X} 1.10$ & 0,364 & 0,278 & Valid \\
\hline 11 & $\mathrm{X} 1.11$ & 0,567 & 0,278 & Valid \\
\hline 12 & $\mathrm{X} 1.12$ & 0,361 & 0,278 & Valid \\
\hline 13 & $\mathrm{X} 1.13$ & 0,691 & 0,278 & Valid \\
\hline 14 & $\mathrm{X} 1.14$ & 0,586 & 0,278 & Valid \\
\hline
\end{tabular}

Sumber : Hasil pengolahan data spss ver.23

Berdasarkan hasil uji validitas Kinerja Pegawai (Y) tabel 3 di atas bahwa hasil pengolahan data variabel kinerja karyawan (Y) menggunakan SPSS ver. 23, menunjukkan seluruh pearson correlation nilai lebih dari $\mathrm{r}_{\text {tabel}}$, merupakan seluruh pernyataan tersebut valid.

\section{b. Uji Realibiltas}

Untuk menentukan apakah instrumen reliabel atau tidak, dimana jika nilai Cronbach Alpha $(a)>0,60$ reliabel sedangkan jika nilai Cronbach Alpha < 0,60 tidak reliabel. Hasil uji reliabilitas, sebagai berikut :

Tabel 4. Hasil Uji Reliabilitas

\begin{tabular}{|c|c|c|c|c|}
\hline No & Variabel & $\begin{array}{c}\text { Cronbach } \\
\text { Alpha } \\
(a)\end{array}$ & $\begin{array}{c}\text { Nilai } \\
\text { Alpha }\end{array}$ & $\begin{array}{c}\text { Hasil } \\
\text { Reliabilitas }\end{array}$ \\
\hline 1 & Motivasi kerja $(\mathrm{X} 1)$ & 0,647 & 0,60 & Reliabel \\
\hline 2 & Disiplin kerja $(\mathrm{X} 2)$ & 0,861 & 0,60 & Reliabel \\
\hline 3 & Kinerja Pegawai $(\mathrm{Y})$ & 0,734 & 0,60 & Reliabel \\
\hline
\end{tabular}

Sumber : Hasil pengolahan data spss ver.23

Berdasarkan hasil uji reliabilitas pada tabel 4 dapat dilihat bahwa cronbach alpha memiliki nilai lebih besar dari nilai alpha yang telah ditetapkan yaitu >0,60 maka dapat disimpulkan bahwa semua variabel dinyatakan reliabel.

\section{c. Uji Normalitas}

Dalam penelitian normalitas data diuji menggunakan uji one sample kolmogorovsmirnov test. Dalam uji one sample kolmogorov-smirnov test, variabel-variabel yang mempunyai asympotic signifinance (2tailed) di atas signifikan 0,05 maka diartikan bahwa variabel-variabel tersebut memiliki distribusi normal dan sebaliknya. Maka dapat disimpulkan, jika signifikansi $<0,05$ distribusi data tidak normal. Namun jika signifikansi $>0,05$ maka distribusi data tersebut normal. Hasil uji normalitas dapat dilihat pada tabel berikut ini :

Tabel 5. Hasil Uji Normalitas one sample kolmogorov-smirnov test pada Variabel Motivasi Kerja $\left(\mathbf{X}_{1}\right)$, Disiplin Kerja $\left(\mathbf{X}_{2}\right)$ dan Kinerja Pegawai (Y)

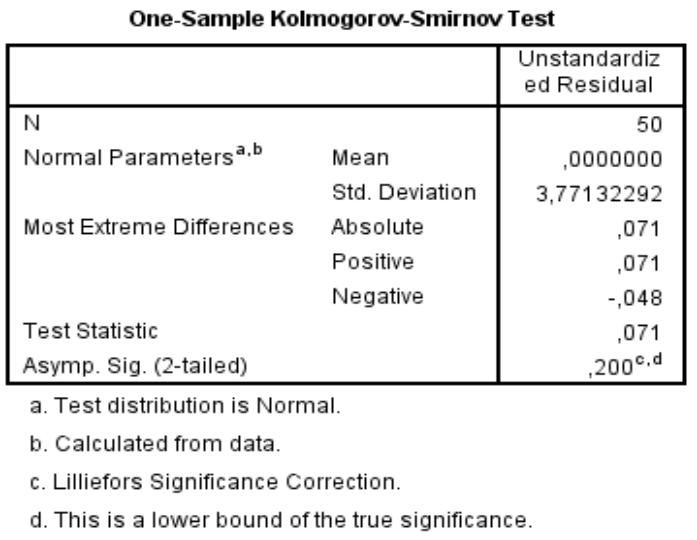


Sumber : Hasil pengolahan data spss ver.23

Pada tabel 5 berdasarkan uji kolmogrovsmirnov, diperoleh hasil output asymp.sig. (2tailed) sebesar 0,200 atau jauh di atas 0,05 menunjukkan bahwa data tersebut terdistribusi secara normal.

\section{d. Uji Multikolinieritas}

Untuk uji multikolinieritas betujuan untuk mengetahui model regresi ditemukan adanya korelasi antar variabel bebas (korelasinya 1 atau mendekati 1) dengan melihat nilai Tolerance dan Variance Inflation factor (VIF), maka dapat disimpulkan jika nilai $\mathrm{VIF}<10$ dan nilai tolerance $>0,10$ maka terjadi multikolinieritas atau sebaliknya.

Tabel 6. Hasil Uji Multikolinieritas

\begin{tabular}{|c|c|c|c|c|c|c|c|c|}
\hline \multirow[b]{2}{*}{ Vata } & & \multicolumn{2}{|c|}{ Urstaniaricosi Cosficients } & \multirow{2}{*}{\begin{tabular}{|c|}
$\begin{array}{c}\text { Stendarized } \\
\text { Coeficierts }\end{array}$ \\
Bthi \\
\end{tabular}} & \multirow[b]{2}{*}{$t$} & \multirow[b]{2}{*}{ Sig } & \multicolumn{2}{|c|}{ Colineant Stristis } \\
\hline & & $B$ & Str Exor & & & & Tilenne & if \\
\hline \multirow[t]{3}{*}{1} & Consianti & 77076 & 7,343 & & 9,221 & 003 & & \\
\hline & WTIASIYERA & .262 & .251 & 965 & $1, \mathrm{MH}$ & 319 & 472 & 2,118 \\
\hline & OSPLNIERJA & -604 & 2ut & -623 & $-3,749$ & .021 & .72 & 2,118 \\
\hline
\end{tabular}

Sumber : Hasil pengolahan data spss ver.23

Pada tabel 6 dapat dilihat bahwa dari hasil uji multikolinieritas di atas, nilai tolerance lebih besar dari 0,10 dan nilai variance inflaction factor (VIF) $<0,10$ dari variabel. Pada variabel motivasi kerja $\left(\mathrm{X}_{1}\right)$ dan disiplin kerja $\left(\mathrm{X}_{2}\right)$ nilai tolerance sebesar $0,472>0,10$. Sedangkan, nilai VIF pada variabel motivasi kerja $\left(\mathrm{X}_{1}\right)$ dan disiplin kerja $\left(\mathrm{X}_{2}\right)$ sebesar $2,118<10$. Maka dapat disimpulkan bahwa tidak terjadi multikolinieritas pada penelitian ini.

\section{e. Uji Heteroskedasitas}

Model regresi yang baik adalah yang berjenis homoskedastisitas atau tidak terjadi heteroskedastisitas. Uji statistik yang digunakan adalah Uji scatter Plot. Dasar analisisnya adalah jika gambar menunjukkan tittik-titik yang menyebar secara acak maka dapat disimpulkan tidak terjadi heteroskedastisitas. Hasil uji ini dapat dilihat pada gambar berikut ini :

\section{Gambar 1. Hasil Uji Heteroskedatisitas}

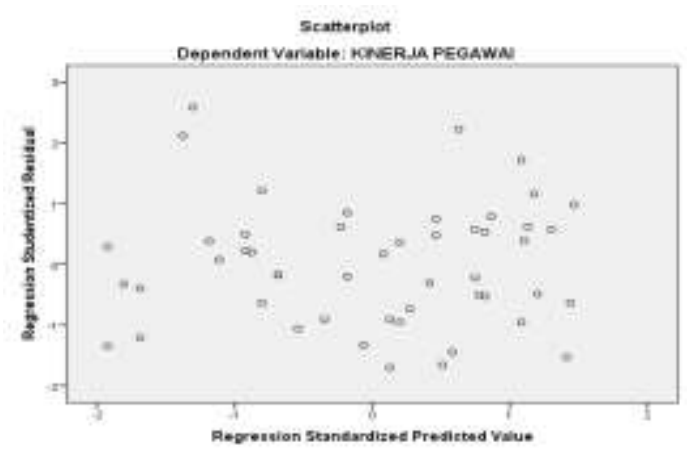

Sumber : Hasil pengolahan data spss ver.23

Pada gambar 1 di atas dapat dilihat bahwa titik-titik yang menyebar secara acak, maka dapat disimpulkan tidak terjadi heteroskedasitas pada uji penelitian.

\section{f. Analisis Regresi Liniear Berganda}

Penelitian ini menggunakan model analisis regresi liniear berganda . Analisis ini menggunakan input berdasarkan data yang diperoleh dari kousioner. Perhitungan statistik yang digunakan dalam analisi liniear berganda yang digunakan dalam penelitian ini menggunakan SPSS versi 23. Hasil pengolahan data dalam penelitian ini sebagai berikut.

Tabel 7. Hasil Uji Analisis Regresi Liniear Berganda

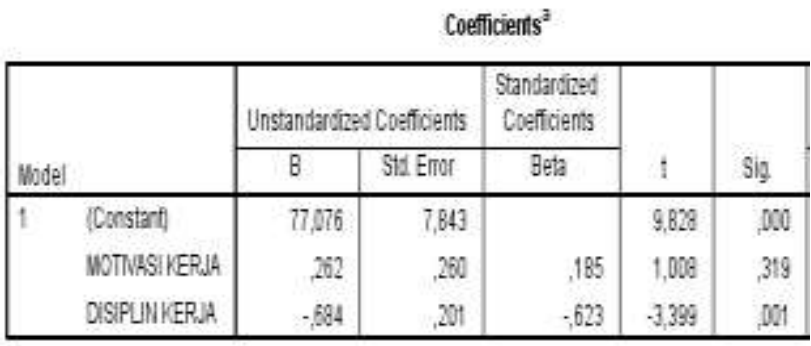

a. Dependent Varable: KINERAA PEGAHA

Sumber : Hasil pengolahan data spss ver.23

Berdasarkan tabel 7 di atas diperoleh hasil persamaan regresi sebagai berikut :

$$
\mathrm{Y}=\mathrm{a}+\mathrm{b}_{1} \mathrm{X}_{1}+\mathrm{b}_{2} \mathrm{X}_{2}+e
$$

$$
\mathrm{Y}=77,076+0,262 \mathrm{X}_{1}+(-0,684) \mathrm{X}_{2}+e
$$

Keterangan : 
$\mathrm{Y}=$ Kinerja Karyawan

$\mathrm{a}=77,076$

$b_{1=} 0,262$

$b_{2=}(-0,684)$

$\mathrm{X}_{1=}$ Motivasi kerja

$\mathrm{X}_{2}=$ Disiplin kerja

$e=$ standard kesalahan (tingkat error)

Dari hasil pengujian regresi linier berganda terdapat persamaan yang menunjukkan koefesien regresi dari 2 (dua) variabel bebas $\left(b_{1}\right)$ bertanda positif $(+)$ sedangkan $\left(b_{2}\right)$ bertanda negatif (-). Bilangan konstanta (a) mempunyai nilai sebesar 77,076 menyatakan bahwa jika mengabaikan Motivasi kerja $\left(\mathrm{X}_{1}\right)$ dan Disiplin kerja $\left(\mathrm{X}_{2}\right)$ maka nilai kinerja pegawai adalah 77,076. Jadi, tetap ada kinerja pegawai walaupun nilai $X_{1}$ dan $X_{2}$ bernilai nol (0) terhadap Y.

1. Koefesien $X_{1}$ menunjukkan bahwa variabel Motivasi kerja $\left(\mathrm{X}_{1}\right)$ berpengaruh terhadap kinerja pegawai. Jika motivasi kerja dinaikkan satu satuan maka kinerja pegawai akan naik sebesar 0,262 , dan sebaliknya jika motivasi kerja diturunkan sebesar satu satuan maka kinerja karyawan akan turun sebesar 0,262. Artinya semakin besar motivasi kerja pada kantor DPRD Provinsi Sumatera Selatan, maka kinerja pegawai akan meningkat. Bahwa hubungannya positif yang artinya apabila motivasi kerja naik, maka kinerjanya naik atau meningkat dan sebalikknya jika, motivasi kerja turun maka kinerja juga turun.

2. Koefesien $X_{2}$ menunjukkan bahwa variabel Disiplin kerja $\left(\mathrm{X}_{2}\right)$ berpengaruh negatif terhadap kinerja pegawai. Jika disiplin kerja dinaikkan satu satuan maka kinerja pegawai akan naik sebesar $-0,684$ dan sebaliknya jika disiplin kerja diturunkan sebesar satu satuan maka kinerja pegawai akan turun sebesar -0,684. Artinya semakin besar disiplin kerja pada kantor DPRD Provinsi Sumatera Selatan maka, kinerja pegawai akan meningkat. Bahwa hubungannya negatif yang artinya apabila disiplin kerja naik maka kinerjanya naik atau meningkat dan sebalikknya jika, disiplin kerja turun maka kinerja

\section{g. Koefesien Determinasi (R)}

Tabel 8. Koefesien Determinasi $\left(\mathbf{R}^{2}\right)$

Model Summary
\begin{tabular}{|l|c|r|r|r|}
\hline Model & R & R Square & $\begin{array}{c}\text { Adjusted R } \\
\text { Square }\end{array}$ & $\begin{array}{c}\text { Std. Error of } \\
\text { the Estimate }\end{array}$ \\
\hline 1 &, $505^{\text {a }}$ &, 255 &, 223 & 3,851 \\
\hline
\end{tabular}
a. Predictors: (Constant), DISIPLIN KERJA, MOTIVASI KERJA
b. Dependent Variable: KINERJA PEGAWAI

Sumber : Hasil pengolahan data spss ver.23

Berdasarkan hasil tabel 8 di atas dapat dilihat bahwa nilai korelasi (R) sebesar = 0,255 yang bearti hubungan variabel bebas Motivasi Kerja $\left(\mathrm{X}_{1}\right)$ dan Disiplin Kerja $\left(\mathrm{X}_{2}\right)$ dengan variabel terikat Kinerja Pegawai (Y) adalah Cukup tinggi.

\section{h. Uji t (secara parsial)}

Uji t merupakan pengujian koefesien regresi parsial individu yang digunakan untuk mengetahui apakah ada pengaruh secara signifikan atau tidak antaravariabel independen $(\mathrm{X})$ dan variabel dependen $(\mathrm{Y})$. Jika signifikansi 0,05, maka $\mathrm{H}_{0}$ ditolak dan $\mathrm{H}_{\mathrm{a}}$ diterima atau jika signifikansi $>0,05$, maka $\mathrm{H}_{0}$ diterima dan $\mathrm{H}_{\mathrm{a}}$ ditolak

Tabel 9. Hasil Uji t (secara parsial)

Coefficierts ${ }^{a}$

\begin{tabular}{|c|c|c|c|c|c|c|}
\hline \multirow[b]{2}{*}{ Mode } & & \multicolumn{2}{|c|}{ Unstandardized Coefficierts } & \multirow{2}{*}{$\begin{array}{c}\begin{array}{c}\text { Standardized } \\
\text { Coefficients }\end{array} \\
\text { Bela }\end{array}$} & \multirow[b]{2}{*}{ t } & \multirow[b]{2}{*}{ Sig. } \\
\hline & & $\theta$ & Sid. Enror & & & \\
\hline \multirow[t]{3}{*}{1} & (Constant) & 77,076 & 7,843 & & 9,828 &, 000 \\
\hline & MOTINASIKERIA & 262 & 260 & 185 & 1,008 &, 319 \\
\hline & DISIPUN KERAA & -684 & 201 & -623 & $-3,399$ &, 001 \\
\hline
\end{tabular}

a. Dependert Variable: KINERJA PEGAR/A

Sumber : Hasil pengolahan data spss ver.23

Berdasarkan hasill uji t pada tabel 9 untuk mengetahui besarnya pengaruh masingmasing variabel independen secara parsial (individu) terhadap variabel dependen adalah sebagai berikut :

\section{i. Uji F (secara simultan)}

Uji $F$ merupakan penguji signifikan persamaan yang digunakan untuk mengetahui seberapa besar pengaruh variabel independen 
(X) secara bersamasama terhadap variabel dependen (Y). Jika signifikansi 0,05, maka $\mathrm{H}_{0}$ ditolak dan $\mathrm{H}_{\mathrm{a}}$ diterima atau jika signifikansi > 0,05 , maka $\mathrm{H}_{0}$ diterima dan $\mathrm{H}_{\mathrm{a}}$ ditolak.

Tabel 10. Hasil Uji F (secara simultan)

ANOVAa

\begin{tabular}{|ll|r|r|r|r|r|}
\hline \multicolumn{1}{|l|}{ Model } & \multicolumn{1}{|c|}{$\begin{array}{c}\text { Sum of } \\
\text { Squares }\end{array}$} & \multicolumn{1}{|c|}{ df } & Mean Square & \multicolumn{1}{c|}{$F$} & \multicolumn{1}{c|}{ Sig. } \\
\hline $1 \quad$ Regression & 238,459 & 2 & 119,230 & 8,041 & $001^{2}$ \\
& Residual & 696,921 & 47 & 14,828 & & \\
Total & 935,380 & 49 & & & \\
\hline
\end{tabular}

a. Dependent Variable: KWERWH PEGAW $[$ ]

b. Predictors: (Consiant), DISIPLIN KERWA, NOTMASIKER_LA

Sumber : Hasil pengolahan data spss ver.23

Berdasarkan hasil Uji F pada tabel 10 di atas menunjukkan bahwa nilai $\mathrm{F}$ sebesar 8,041 sementara untuk $\mathrm{f}_{\text {tabel }}$ dengan sig. $a=$ 0,05 dan $\mathrm{df}=2$ maka didapat $\mathrm{f}_{\text {tabel }}$ sebesar 3,20. Nilai $f_{\text {hitung }}$ lebih besar dari $f_{\text {tabel }}(8,041>3,195)$ dan Sig. 0,000 dapat disimpulkan model regresi ini dapat digunakan. Karena tingkat sig. lebih kecil dari $0,05(0,001<0,05)$ bahwa hasilnya $\mathrm{H}_{0}$ ditolak dan $\mathrm{H}_{\mathrm{a}}$ diterima sehingga dapat dikatakan bahwa ada hubungan yang signifikan antara variabel motivasi kerja dan disiplin kerja secara simultan atau bersamasama terhadap kinerja pegawai pada kantor DPRD Provinsi Sumatera Selatan.

\section{Pembahasan}

Adapun pembahasan penulis terhadap penelitian ini adalah sebagai berikut :

\section{Pengaruh Motivasi kerja terhadap Kinerja pegawai}

Berdasarkan tabel 4.15 diatas variabel motivasi kerja mempunyai nilai sig. 0,319 < 0.05 dan nilai $\mathrm{t}_{\text {hitung }}<\mathrm{t}_{\text {tabel }}(1,008<1,677)$. Hal ini berarti $\mathrm{H}_{\mathrm{a}}$ diterima dan $\mathrm{H}_{\mathrm{o}}$ ditolak yang berarti variabel motivasi kerja berpengaruh positif dan tidak signifikan terhadap kinerja pegawai.

Hasil pengujian hipotesis pertama menunjukkan bahwa motivasi kerja tidak signifikan terhadap kinerja pegawai pada kantor DPRD Provinsi Sumatera Selatan. Dalam penelitian ini kemungkinan lebih disebabkan pada karakteristik pegawai yang sebagian besar tingkat pendidikan S1 dan karakteristik jenis kelamin dari responden kebanyakan laki-laki. Dengan tingkat pendidikan S1 pegawai kurang memiliki motivasi untuk mendapatkan prestasi kerja, pengembangan diri, dari pekerjaan itu sendiri dan mendapat pengakuan. Karakteristik pekerjaan dari responden sebagai staf kantor kurang memberi peluang bagi pegawai untuk meningkatkan karir. hal ini menjadi penguat bahwa motivasi kerja tidak berpengaruh terhadap kinerja pegawai.

Selain hal tersebut diatas budaya kerja dan sistem kerja yang sudah terbentuk lama di kantor DPRD Provinsi Sumatera Selatan merupakan salah satu alasan yang menyebabkan motivasi kerja tidak berpengaruh terhadap kinerja pegawai. Tanpa motivasi kerja pegawai tetap akan terbawa untuk bekerja dengan baik sesuai dengan kebijakan dan sistem kerja yang telah terbentuk di lingkungan kantor DPRD Provinsi Sumatera Selatan.

Dan ada variabel lain seperti lingkungan kerja, budaya kerja, kompensasi, ataupun yang lainnya yang lebih mempengaruhi kinerja pegawai dibandingkan motivasi kerja. Hasil penelitian ini mendukung hasil penelitian Dody Chrisnanda (2017) dimana motivasi kerja tidak signifikan terhadap kinerja pegawai.

\section{Pengaruh Disiplin kerja terhadap \\ Kinerja pegawai}

Hasil pengujian hipotesis kedua menunjukkan bahwa disiplin kerja memiliki pengaruh negatif dan signifikan terhadap kinerja pegawai. semakin tinggi disiplin kerja maka semakin tinggi pula kinerja pegawai Disiplin kerja dipengaruhi oleh dapat dipengaruhi oleh semangat kerja pegawai, tingkat kompensasi yang diberikan, serta kepuasan kerja pegawai. Dimana pegawai dengan semangat kerja yang tinggi cenderung akan bekerja dengan lebih baik, tepat waktu, dan tidak pernah membolos, pegawai akan semangat untuk berangkat kerja sehingga disiplin kerja nya menjadi tinggi. Dengan dilandasi dengan aspek aspek di atas maka kedisplinan kerja akan berpengaruh besar pada kinerja pegawai. Ketika tingkat disiplin kerja suatu perusahaan itu tinggi maka diharapkan pegawai akan bekerja lebih baik, sehingga produktivitas instansi meningkat. Selain itu disiplin kerja yang baik akan meningkatkan efisiensi kerja semaksimal mungkin, tidak menghabiskan waktu yang banyak bagi instansi untuk sekedar melakukan pembenahan diaspek kedisplinan tersebut dan waktu dapat digunakan untuk mencapai tujuan instansi. 
Pengaruh disiplin kerja terhadap kinerja pegawai telah dikemukakan dalam penelitian Ariana (2013). Dalam penelitiannya disebutkan bahwa instansi bisa lebih memperhatikan kemampuan karyawan, balas jasa terhadap pegawai, sanksi terhadap pelanggaran disiplin, pengawasan yang lebih ketat dalam upaya meningkatkan atau memperbaiki kinerja pegawai. Hal-hal tersebut membuktikan bahwa disiplin kerja merupakan faktor penting dalam meningkatkan kinerja pegawai. Dengan adanya disiplin kerja yang baik dari pegawai seperti datang tepat waktu, melaksanakan pekerjaan sesuai dengan apa yang telah ditetapkan oleh instansi, mentaati peraturan maka akan dapat meningkatkan kinerja dari pegawai tersebut sehingga target akan tercapai.

\section{Pengaruh Motivasi kerja dan Disiplin kerja terhadap Kinerja pegawai}

Hasil pengujian hipotesis ketiga menunujukkan bahwa motivasi kerja dan disiplin kerja secara bersama-sama memiliki pengaruh terhadap tingkat kinerja pegawai. hal ini menunjukkan bahwa untuk meningkatkan kinerja pegawai harus dilakukan secara bersama-sama untuk dapat meningkatkan kinerja pegawai. Hasil penelitian ini mendukung hasil penelitian Heny Sidanti (2015) dimana terdapat pengaruh motivasi kerja dan disiplin kerja terhadap kinerja pegawai. Menurut Wilson Bangun (2012:230), menjelaskan bahwa peningkatan kinerja merupakan hal yang diinginkan.

baik dari pihak pemberi kerja maupun para pekerja. Pemberi kerja menginginkan kinerja pegawainya, baik untuk kepentingan peningkatan hasil kerja dan keuntungan instansi. Disisi lain, para pekerja berkepentingan untuk pengembangan diri dan promosi pekerjaan. Peningkatan kinerja pegawai juga akan berpengaruh terhadap produktivitas instansi.

\section{SIMPULAN DAN SARAN Simpulan}

Penelitian ini bertujuan untuk mengetahui pengaruh dari motivasi kerja dan disiplin kerja terhadap kinerja pegawai pada kantor DPRD Provinsi Sumatera Selatan. Berdasarkan dari hasil analisis dan pembahasan yang dilakukan dengan menggunakan regresi linier berganda dapat dilihat dari kesimpulan berikut ini.
1. Motivasi kerja tidak memiliki pengaruh yang positif dan signifikan terhadap kinerja pegawai kantor DPRD Provinsi Sumatera Selatan.

2. Disiplin kerja memiliki pengaruh yang positif dan signifikan terhadap kinerja pegawai kantor DPRD Provinsi Sumatera Selatan

3. Motivasi kerja dan Disiplin kerja memiliki pengaruh yang positif dan signifikan secara bersama-sama terhadap kinerja pegawai kantor DPRD Provinsi Sumatera Selatan.

\section{Saran}

Berdasarkan kesimpulan yang diperoleh di atas, saran yang dapat diberikan adalah sebagai berikut :

1. Sebaiknya instansi melakukan peningkatan dalam memberikan motivasi kerja kepada pegawai. Untuk meningkatkan kinerja pegawai dapat dilakukan dengan cara memberikan motivasi bagi pegawai agar semangat berkerja dan memiliki kreatif dalam bekerja. Perlu pula kepekaan untuk sesegera mungkin membantu pekerjaan rekan kerja setelah pekerjaan sendiri selesai, sehingga disamping melakukan pekerjaan kantor, pegawai juga melakukan interaksi antara sesama pegawai.

2. Diharapkan kantor DPRD Provinsi Sumatera Selatan lebih meningkatkan lagi disiplin kerja pegawai dengan cara memberikan masukan kepada pegawai tentang kedisiplinan dalam bekerja agar nantinya pegawai akan selalu datang bekerja tepat waktu dan tidak meninggalkan kantor sebelum waktunya sehingga nanti akan membuat disiplin pegawai menjadi lebih baik lagi dan juga dapat dengan pemberian sanksi-sanksi tegas jika pegawai melanggar peraturan dan tidak disiplin.

3. Bagi Peneliti selanjutnya agar menambah vaiabel lain yang dapat mempengaruhi kinerja agar hasil penelitiannya lebih akurat.

\section{E. DAFTAR RUJUKAN}

Ayer Johanes Eliezer, Pangemanan Lyndon R.J, Ruri Yolanda P.I. 2016. Pengaruh Motivasi dan Disiplin Kerja terhadap Kinerja Pegawai pada Dinas Pertanian Kabupaten Supiori. AgriSosioEkonomi Unsrat, ISSN 1907- 
4298, Volume 12 Nomor 3A, November 2016.

Fahmi, Irfam. 2011. Manajemen Kinerja Teori dan Aplikasi. Bandung:

ALFABETA,cv

Hendri, Edduar. 2013. Analisis Faktor-Faktor yang Mempengaruhi Kinerja Pegawai Pada Fakultas Ekonomi Universitas PGRI Palembang. Jurnal Media Wahana Ekonomika Vol.10 N0.3 Oktober 2013.

Hasibuan, Malayu S.P. 2011. Manajemen Sumber Daya Manusia. Jakarta: PT Bumi Aksara.

Hasibuan, Malayu S.P. 2013. Manajemen Sumber Daya Manusia. Jakarta: PT Bumi Aksara.

Kasmir, 2016. Manajemen Sumber Daya Manusia (Teori dan Praktik). Jakarta: PT Rajagrafindo Persada.

Liyas Jeli Nata, Primadi Reza.2017. Pengaruh Disiplin Kerja terhadap Kinerja Karyawan pada Bank Perkreditan Rakyat. Al Masraf: Jurnal Lembaga Keuangan dan Perbankan-Volume 2, Nomor 1. Januari-Juni 2017.

Mangkunegara. 2017. Manajemen Sumber Daya Manusia. Bandung: PT Remaja Rosdakarya.

Moeheriono. 2014. Pengukuran Kinerja Berbasis Kompotensi Edisi Revisi. Jakarta: Raja Grafindo Persada.

Mulyadi, 2015. Manajemen Sumber Daya Manusia. Bogor: Penerbit In Media.

Priyatno, Duwi. 2018. SPSS Panduan Mudah Olah Data Bagi Mahasiswa dan Umum. Yogyakarta: cv.Andi offset.

Rivai, V,.\& Sagala,D.E. 2013. Manajemen Sumber Daya Manusia untuk Perusahaan. Jakarta: Rajawali Pers.

Sinambela, Lijan Poltak. 2016. Manajemen Sumber Daya Manusia Membangun Tim Kerja yang Solid untuk Meningkatkan Kinerja. Jakarta: PT Bumi Aksara.

Siregar, Syofian. 2013. Metode Penelitian Kuantitatif. Jakarta:PT. Fajar Inter Pratama Mandiri.

Sugiyono, 2017. Metode Penelitian Manajemen. Bandung: Alfabet cv.

Sutrisno, Edy. 2012. Manajemen Sumber Daya Manusia. Jakarta: Kencana Prenada Media Group.
Sutrisno, Edy. 2014. Manajemen Sumber Daya Manusia. Jakarta: Kencana Prenada Media Group.

Sujarweni, V. Wiratna. 2015 Statistik Untuk Bisnis dan Ekonomi. Yogyakarta: Pustaka Baru Press.

Sujarweni, V. Wiranta. 2019. Metodelogi Penelitian Bisnis \& Ekonomi. Yogyakarta: Pustaka Baru Press.

Wibowo, 2016 Manajemen Kinerja-Edisi Kelima. Jakarta: PT Rajagrafindo Persada 
